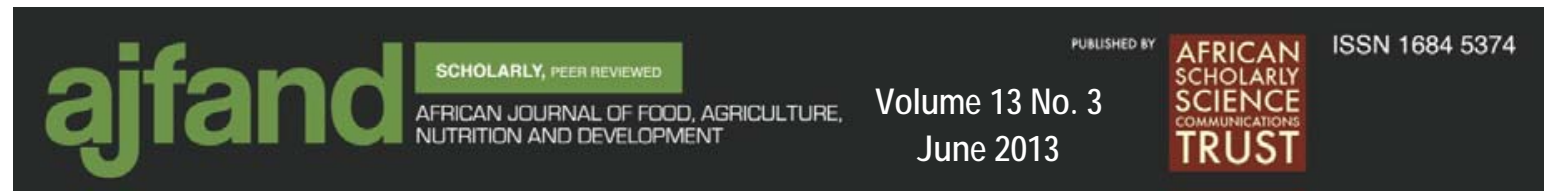

\title{
PERFORMANCE OF IMPROVED BEAN VARIETIES IN KASULU AND KIBONDO DISTRICTS OF KIGOMA REGION, TANZANIA
}

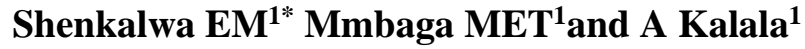

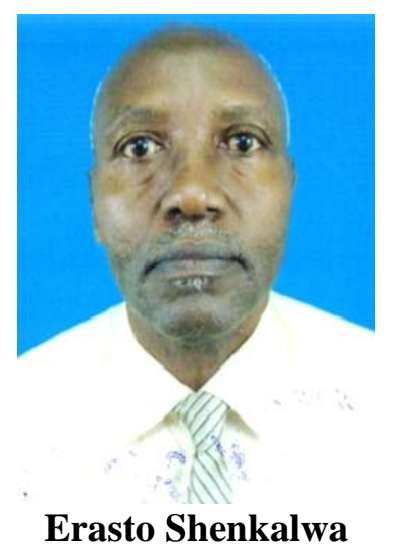

Erasto Shenkalwa

*Corresponding author email: shenkalwa2002@yahoo.com

${ }^{1}$ Agricultural Research Institute, Tumbi, P. O. Box 306, Tabora, TANZANIA 


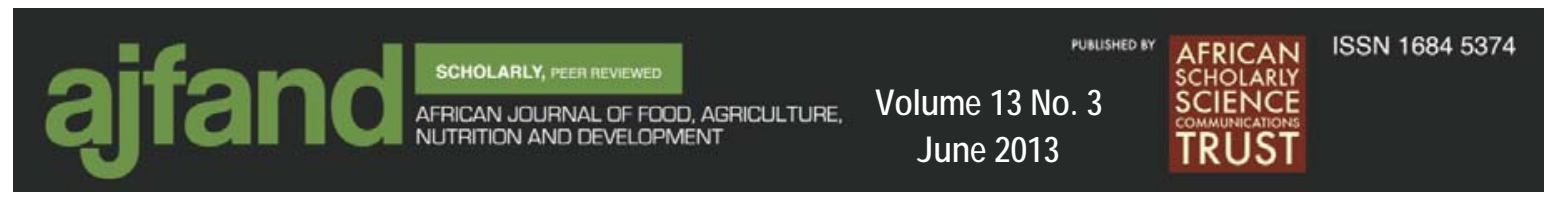

\section{ABSTRACT}

A project aimed at improving bean production in Kigoma Region was carried out from 2008/09 to 2010/11 in Kasulu and Kibondo districts. Soils at trial sites varied from sandy clay loams to clay, mostly acidic with $\mathrm{pH}$ water varying from 4.5 to 6.3 (mean $5.5 \pm 0.5$ ) with low to medium $(1.86 \% \pm 0.57 \%)$ organic carbon (OC), low $(0.15 \pm 0.05)$ total nitrogen $(\mathrm{N})$, and low to medium $(5.27 \pm 5.4 \mathrm{mg} / \mathrm{kg})$ available phosphorus (P). Five improved cultivars, Jesca, Lyamungo 90, Selian 97, Uyole Njano and Uyole 98 were evaluated for yield in farmers' fields, and assessed for farmer acceptability through a questionnaire. The varieties were compared to Kigoma Yellow, a local variety known also as Mburamutwe. The experimental design was Randomized Complete Block with farmers as replicates. Plot size was $10 \mathrm{~m}$ by $10 \mathrm{~m}$ and spacing was $50 \mathrm{~cm}$ by $20 \mathrm{~cm}$. Yield data were analyzed using MS X-Cel and GenStat Discovery edition. Farmers' assessment data were analyzed by SPSS (V 11.5). There were positive significant $(\mathrm{p}<0.05)$ correlations between bean yields of the varieties Jesca, Lyamungo 90, and Selian 97 and soil exchangeable potassium (K), and positive significant $(\mathrm{p}<0.05)$ correlations between Kigoma yellow and soil available $\mathrm{P}$ and between Selian 97 and soil total nitrogen in the first season. In Kasulu, average yields were less than those obtained in Kibondo and ranged from 495 $\pm 169 \mathrm{kgha}^{-1}$ for Jesca to $874 \pm 583 \mathrm{kgha}^{-1}$ for Uyole 98, compared to the range of 673 $\pm 283 \mathrm{kgha}^{-1}$ for Jesca to $1602 \pm 333 \mathrm{kgha}^{-1}$ for Uyole Njano in Kibondo district. The results showed that Uyole Njano and Uyole 98 gave significantly $(\mathrm{p}<0.05)$ higher yields than all the other varieties. Farmers' assessed uncooked beans for seed size, shape, color, marketability and over all preference. Assessment of cooked beans considered taste, smell, soup appearance, soup color and consistence. This assessment ranked Kigoma yellow and Uyole Njano as number one and two, respectively for both uncooked and cooked beans. Lyamungo 90 and Uyole 98 ranked third and fourth, respectively for uncooked beans. There were no differences in costs of production between the different bean varieties. Economic analysis (Table 3) showed that Uyole Njano produced the highest yield value per unit cost of production followed by Uyole 98. Introduction of Uyole Njano and Uyole 98 bean varieties for production in the two districts is recommended.

Key words: Bean varieties, yields, farmers’ assessment 


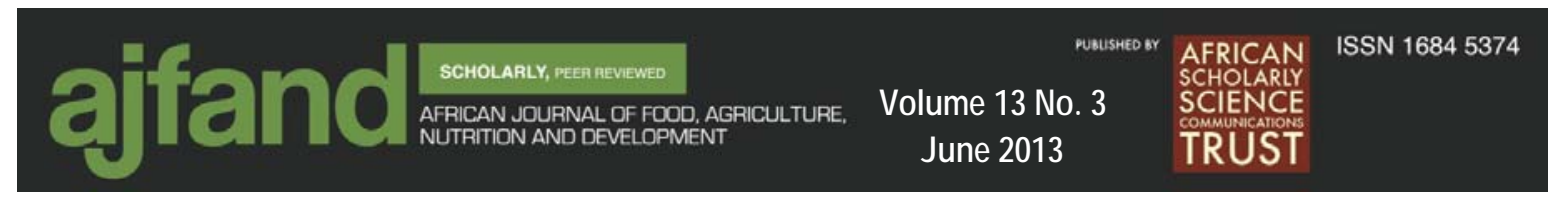

\section{INTRODUCTION}

Beans are a warm season crop that does not require an excessive amount of moisture. Depending on the soil and climatic factors, the requirement is met with $300-600 \mathrm{~mm}$ rainfall [1]. Some rain is required during the flowering and pod setting stages [2]. Field beans are adapted to a wide range of soils, but are grown most successfully on well drained soils of medium texture (loams). The optimum $\mathrm{pH}$ for field beans is between 6.0 and 7.5 [3]. Beans are an important and relatively inexpensive dietary source of protein for the residents of Kigoma $[4,5]$. They contain protein in a range between 16 and 34\% [6]. Beans also contain carbohydrates (up to 60g per $100 \mathrm{~g}$ ), vitamins (up to $394 \mu \mathrm{g}$ vitamin B9 and $0.8 \mathrm{mg}$ vitamin B5 per $100 \mathrm{~g}$ ) and minerals (143 mg Ca, $140 \mathrm{mg} \mathrm{Mg,} 8 \mathrm{mg}$ Iron and $3 \mathrm{mg} \mathrm{Zn}$ per 100g seeds). The crop is therefore the second most important food crop after maize for Kigoma Region.

Beans provide cash income for many people in the region and production fits conveniently into the complex crop production systems in the region. It is among five crops ranked by farmers as most important in the western zone [7]. The majority of farmers grow Kigoma yellow, a variety locally known as Mburamutwe. It yields between 200 and $600 \mathrm{~kg} \mathrm{ha}^{-1}$ under farmers' management conditions and up to 1,000 $\mathrm{kg} \mathrm{ha}^{-1}$ under improved management (own data). Improved bean cultivars produce 1.5 to 3-4 tons ha-1 [8]. According to Kanyeka 2007, Tanzanian improved bean varieties yield 1.5 to 3.5 tons ha-1 [9]. In this emphasis was placed on the participatory testing of promising bean cultivars on farmer's fields in Kasulu and Kibondo districts of Kigoma Region. The varieties used were developed by Lyamungu, Selian and Uyole Research stations. The overall objective of this research was to evaluate improved bean cultivars for yield under farmers' conditions and determine the economics of production of the different bean cultivars in Kasulu and Kibondo districts of Kigoma Region.

\section{MATERIALS AND METHODS}

The trial was carried out in Kasulu and Kibondo districts of Kigoma Region. Kasulu district is located between longitudes $25^{\circ} 45^{\prime}$ and $30^{\circ} 45^{\prime}$ east of Greenwich (E), and latitudes $3^{0} 45^{\prime}$ and $4^{0} 55^{\prime}$ south (S) of the equator [Regional Agriculture Adviser, personal communication (RAA)] at altitudes from 900 to 1800 meters above sea level (m.a.s.l). It is divided into two major land forms, the cool highlands and the relatively warm lower plains. The trials were located in the lower plains at around $30^{\circ} 15^{\prime}$ to $17^{\prime}$ E and $4^{0} 37^{\prime}$ to $40^{\prime} \mathrm{S}$ at 1138 to 1139 m.a.s.l.

Kibondo district lies between longitudes $30^{\circ} 12^{\prime}$ and $30^{\circ} 30^{\prime} \mathrm{E}$ and latitudes $2^{0} 55^{\prime}$ and $5^{0} 00^{\prime} \mathrm{S}$ [RAA, personal communication] at altitudes between 900 and 1700 m.a.s.l. Most of the agricultural activities in the district are concentrated in the high lands above 1100 m.a.s.l. The trials in this district were located around $30^{\circ} 44^{\prime}$ to $55^{\prime} \mathrm{E}$ and $3^{0} 15^{\prime}$ to $33^{\prime} \mathrm{S}$ at altitudes between 1300 and $1368 \mathrm{~m}$.a.s.l.

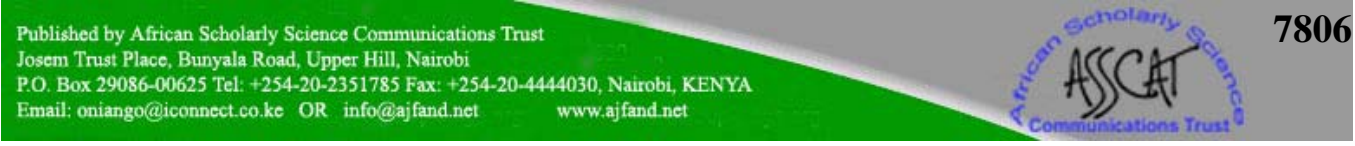




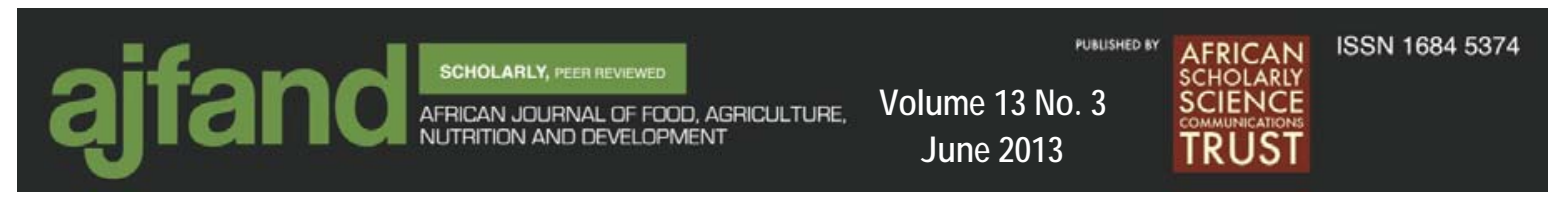

Twenty farmers participated in the bean evaluation. District and Village agricultural extension officers assisted in selection of ten farmers from each district based on their willingness to collaborate. Initial soil fertility status was assessed by analysis of soil samples taken from each trial site at the beginning of the trial in the first season. The samples were analyzed by the National Soils Laboratory at Mlingano, Tanga, for Texture, pH, Exchangeable bases, Organic carbon (OC), Total nitrogen (N), Cation Exchange Capacity (CEC), Available phosphorus (Bray 1) and Electrical conductivity (EC). These Soils varied from sandy clay loams to clay.

The treatments were five improved bean varieties, Jesca, Lyamungo 90, Uyole Njano, Uyole 98 and Selian 97 developed from research and Kigoma yellow (Mburamutwe) a control. All are suitable for an altitude of 1000 -1500 m.a.s.l and mature within 80 90 days after sowing. They can produce between two and 3.5 tons ha ${ }^{-1}$ under optimum management. The improved varieties were bred for resistance to the six most common bean diseases, namely; anthracnose, angular leaf spot, leaf rust, halo blight and bean common mosaic virus [9].

Fertilizer NPK was applied at planting at the rate of 825 grams of NPK 10:18:24 per plot, which supplied the equivalent of $16.5 \mathrm{~kg} \mathrm{ha}^{-1} \mathrm{~N}, 29.7 \mathrm{~kg} \mathrm{ha}^{-1} \mathrm{P}_{2} \mathrm{O}_{5}$ and $39.6 \mathrm{~kg}$ $\mathrm{ha}^{-1} \mathrm{~K}_{2} \mathrm{O}$. Plot size was $10 \mathrm{~m} \times 10 \mathrm{~m}$ at a spacing of $50 \mathrm{~cm} \times 20 \mathrm{~cm}, 2$ seeds per hill, ten rows per plot.

In the first season, farmers participated in assessing the bean varieties on pests and diseases infestation, as disease stress is among important factors limiting bean production [10]. Farmers, in some cases with the assistance of village extension staff, did bean harvesting. Extension staff and researchers also recorded yields. During the last two seasons a preventive fungicide and pesticide were applied and therefore no pests and diseases were recorded.

Yield data were entered into the X-cel computer programme and subjected to analysis of variance (ANOVA) using the GenStat Discovery statistical package [11]. Simple linear correlation between first year yields and soils analytical data were performed using the X-cel programme.

Farmers assessed the second and third seasons' uncooked bean seeds for size, shape, color, general appearance and possibility of market acceptance. They also assessed cooked beans for taste, smell, soup appearance, color and consistence. The assessment was done using scores from 1-5, where 1 was minimum and 5 was maximum. Farmers' assessment data were coded, entered into and analyzed by the SPSS package [12]. 


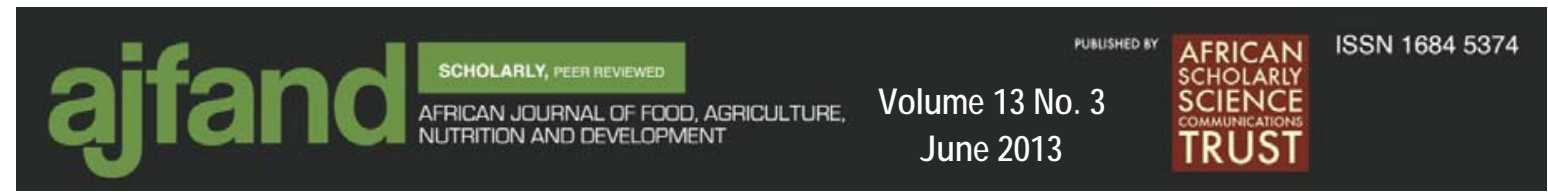

\section{RESULTS}

\section{Soils}

The soils varied from sandy clay loams to clay, most of them with $\mathrm{pH}$ water ranging between 5.0 and 5.9 (mean $5.5 \pm 0.5$ ). At Kasanda village in Kibondo district, one site was strongly acidic with $\mathrm{pH}$ water of 4.5 and one site had a $\mathrm{pH}$ of 6.3. The most acidic soil had the poorest bean yields, and the site with $\mathrm{pH} 6.3$ attained the highest yields. This trend was not observed in Kasulu district. Low $\mathrm{pH}<5.0$ is considered to be limiting bean growth [13]. The CEC ranged from low to high (mean $25.21 \pm$ 12.77). Organic carbon (OC) varied from $1.17 \%$ to $3.26 \%(1.86 \% \pm 0.57 \%)$, total $\mathrm{N}$ from $0.10 \%$ to $0.24 \%,(0.15 \% \pm 0.05 \%)$, total exchangeable bases from 3.67 to 28.76 $\mathrm{Me} / 100 \mathrm{~g}$ soil $(13.76 \pm 6.96 \mathrm{Me} / 100 \mathrm{~g}$ soil) and available phosphorus from 1.01 to $14.29(5.27 \pm 5.4) \mathrm{mg} / \mathrm{kg}$ of soil. (2009 soil analysis data).

\section{Growth, pests and diseases}

Plant vigour and canopy cover differences between four varieties were observed in the first season only, where Jesca and Kigoma yellow were poorest. Plant vigour scores were $3.28 \pm 0.60$ for Jesca and $3.30 \pm 0.55$ for Kigoma yellow, while canopy cover scores were $3.18 \pm 0.59$ for Jesca and 3.23 \pm 0.55 for Kigoma yellow (Figure 1).

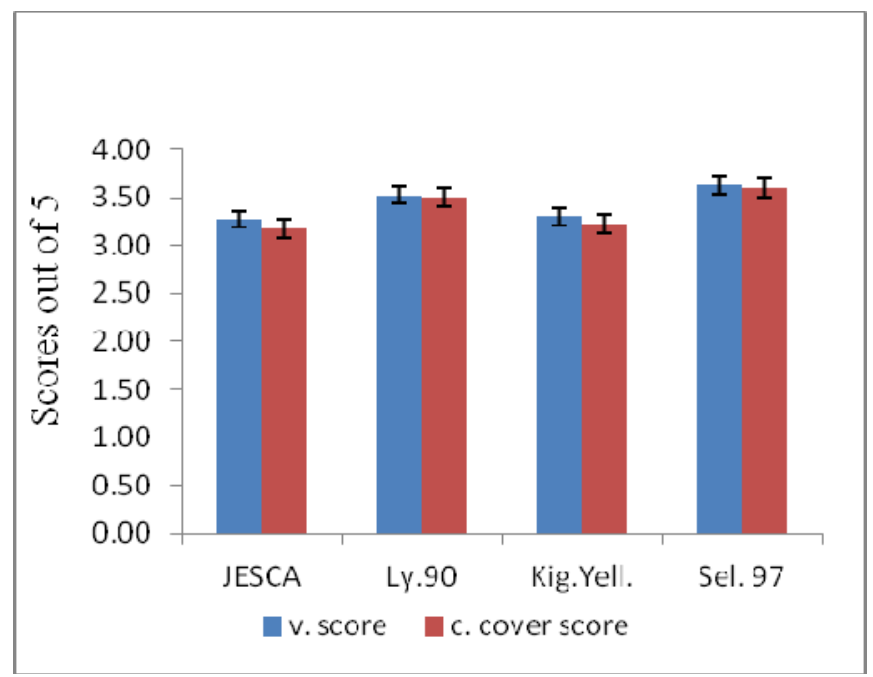

Figure 1: Mean scores for growth vigour and canopy cover as observed in the first season

Similarly, pests and diseases were seen in the first season. Average scores for the diseases most observed were $3.04 \pm 0.30$ for leaf rust, $3.79 \pm 0.25$ for anthracnose and $3.95 \pm 0.05$ for root rot. The varieties that showed least tolerance to leaf rust were Kigoma yellow (2.78 \pm 0.30$)$ and Jesca (2.70 \pm 0.30$)$. Lyamungo 90, which was bred for resistance to anthracnose, was affected most by the disease (tolerance score $3.40 \pm$ 


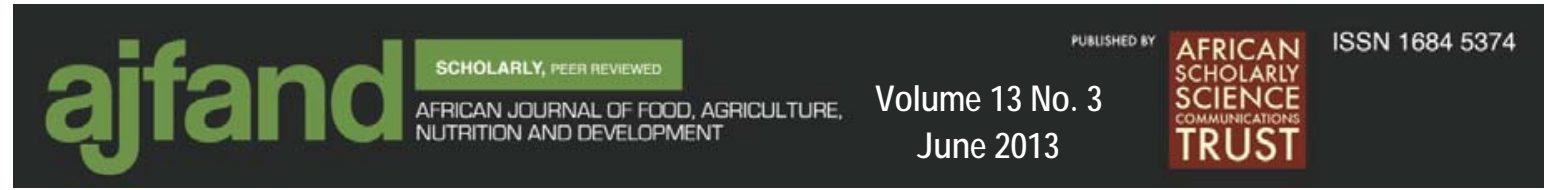

0.72). Root rot occurred most in the local variety, Kigoma yellow. The tolerance score for a resistant variety was set at 5 .

Leaf chewing insects affected all varieties with a mean score of $3.31 \pm 0.08$. They were assessed by scoring the proportion of leaves chewed. Aphids and flower beetles were occasionally observed in some fields. The local variety was affected most by bean maggots, with a mean tolerance score of $3.63 \pm 0.07$.

\section{Yield performance}

Average bean yields ranged from $584 \pm 244.2 \mathrm{kgha}^{-1}$ for JESCA to $1199 \pm 540.4$ $\mathrm{kgha}^{-1}$ for Uyole njano (Figure 2).

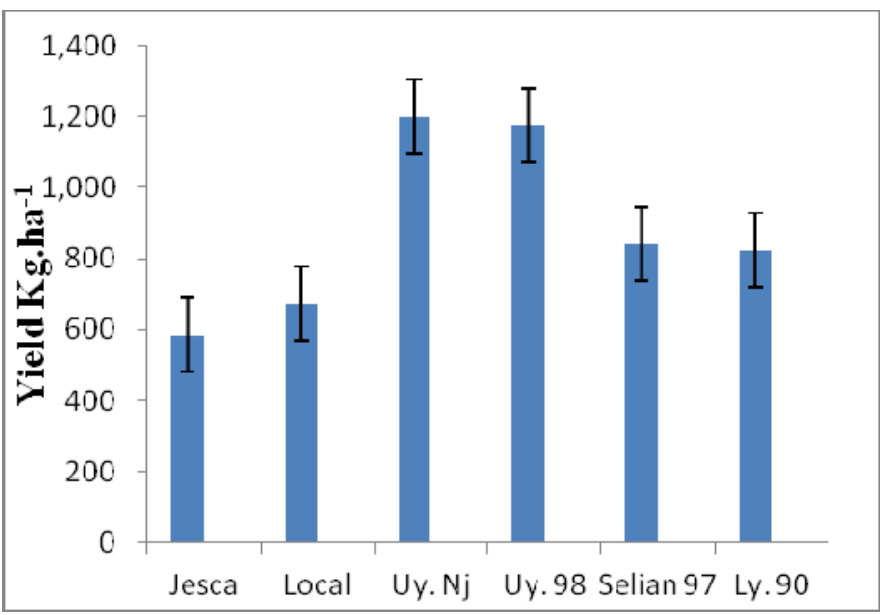

Figure 2: Average bean yields (kg ha-1) for the trial

The yields of Uyole njano ranged from $898 \mathrm{~kg} \mathrm{ha}^{-1}$ to 2,094 kg ha-1 in Kibondo district and $433 \mathrm{~kg} \mathrm{ha}^{-1}$ to $1513 \mathrm{~kg} \mathrm{ha}^{-1}$ in Kasulu district.

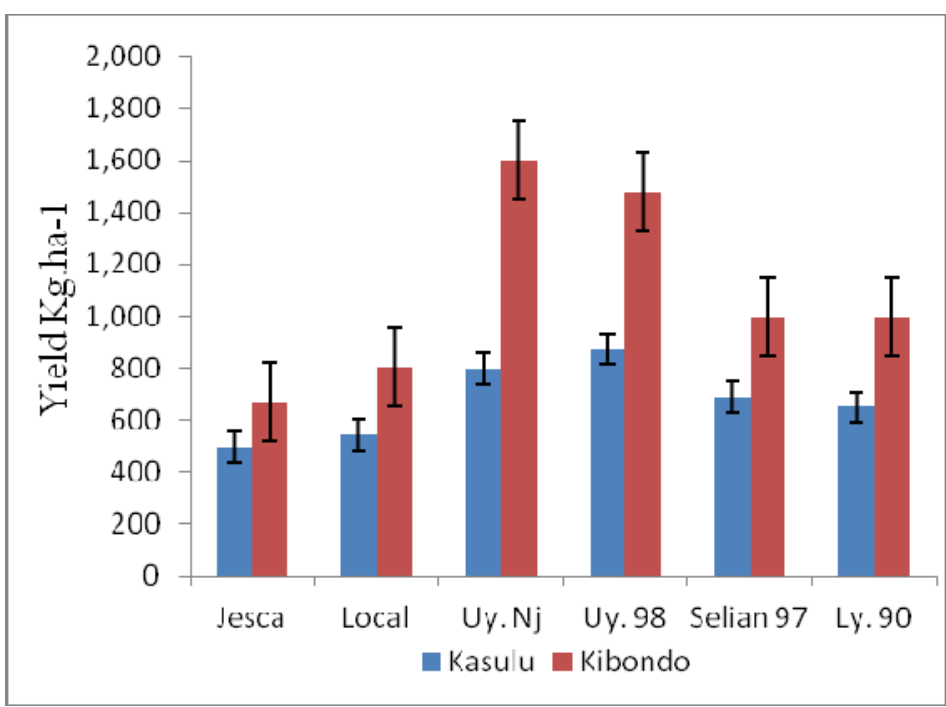

Figure 3: Average bean yields (kg ha-1) for Kasulu and Kibondo districts 


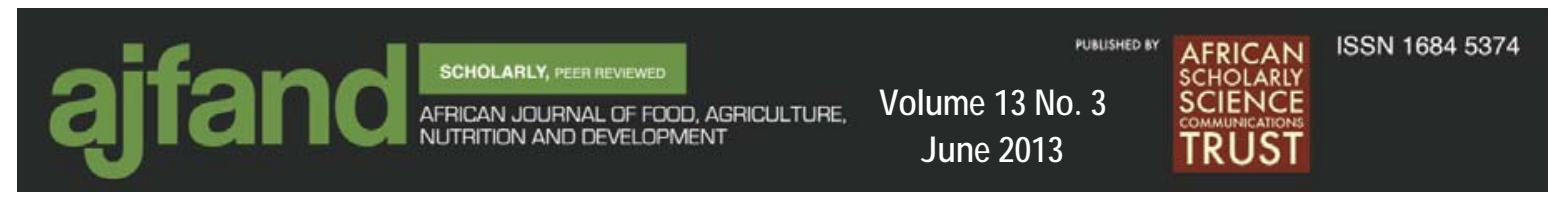

Average yields in Kasulu district were less than those obtained in Kibondo district. They ranged from $495 \pm 169 \mathrm{~kg} \mathrm{ha}^{-1}$ for Jesca to $874 \pm 583 \mathrm{~kg} \mathrm{ha}^{-1}$ for Uyole 98, compared to the range of $673 \pm 283 \mathrm{~kg} \mathrm{ha}^{-1}$ for Jesca to $1602 \pm 333 \mathrm{~kg} \mathrm{ha}^{-1}$ for Uyole Njano in Kibondo district (Figure 3).

The mean yield of Uyole Njano was statistically $(\mathrm{P}<0.05)$ similar to that of Uyole 98, which was $1175 \pm 564 \mathrm{~kg} \mathrm{ha}^{-1}$. Uyole 98 yields ranged from $717 \mathrm{~kg} \mathrm{ha}^{-1}$ to $1863 \mathrm{~kg}$ $\mathrm{ha}^{-1}$ in Kibondo district and $363 \mathrm{~kg} \mathrm{ha}^{-1}$ to 2,052 $\mathrm{kg} \mathrm{ha}^{-1}$ in Kasulu district. The average yield for the local variety was $674 \pm 265 \mathrm{~kg} \mathrm{ha}^{-1}$.

\section{Farmers' assessment}

Farmers' assessment of uncooked beans considered seed size, shape, color, marketability and over all preference while assessment on cooked beans considered taste, smell, soup appearance, color and consistence. This assessment was done for two seasons.

\section{Uncooked beans}

The most preferred varieties were Kigoma yellow (preference score $3.98 \pm 1.33$ ) and Uyole 98 (preference score $3.62 \pm 1.02$ ) followed by Uyole njano (preference score $3.52 \pm 1.66$ ), Lyamungo 90 (preference score $3.51 \pm 0.97$ ) and Selian 97 (preference score $3.38 \pm 1.77$ ) in that order. The least preferred variety was Jesca (preference score $3.32 \pm 1.60$ ). Bean seed size ranged from small to large, but the majority of farmers $(>70 \%)$ considered all varieties to have medium to large sized beans. Majority of farmers scored the shape of Kigoma yellow (3.91 \pm 1.25$)$ and Jesca (3.43 \pm 1.33 ) as good. All other varieties were considered to be moderately shaped. Mean scores for color did not differ much between varieties, but showed that the colors of Kigoma yellow (4.00 \pm 1.13$)$ and Lyamungo 90 (3.60 \pm 0.86$)$ were considered as good. Colors of the other varieties were considered to be moderate. The majority of respondents (73.9\%) considered Kigoma yellow to have moderate to very high marketability potential in Kigoma Region, followed by Uyole Njano (69.3\%). These two varieties are very similar in appearance. Combining the two years' assessment of uncooked beans ranked Kigoma yellow as the number one variety and Uyole Njano as number two.

\section{Cooked beans}

Cooked beans were assessed for attractiveness, taste, smell, soup color and density, and over all preference. Most respondents (>75\%) thought Kigoma yellow, Lyamungo 90, Uyole 98 and Uyole Njano varieties were attractive to very attractive when cooked. The majority of participants (>80\%) said that Kigoma yellow, Uyole 98 and Selian 97 had good to very good taste while 78\% said Uyole Njano and Lyamungo 90 had moderate to good taste. The smell of all varieties when cooked was found to be moderate to very good by over $73 \%$ of the respondents. Bean soup color was assessed by over $70 \%$ of the respondents as moderate to very good for all varieties when cooked. Bean soup density was considered by $83.2 \%$ of respondents to be light to

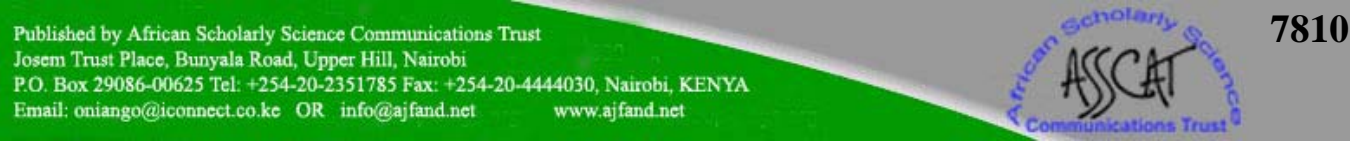




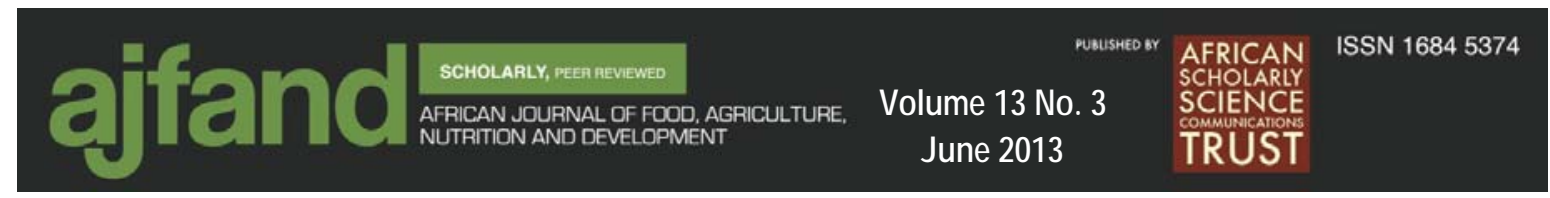

heavy for Uyole njano, moderate to very heavy for Jesca (87.7\%), Uyole 98 (77\%), Lyamungo 90 (80\%) and Kigoma yellow (74.9\%) and moderate to heavy (67.7\%) for Selian 97.

After assessing individual parameters for each variety when cooked, the respondents were asked for their general preference. Varieties were moderately to very highly preferred by over 90\% of respondents for Kigoma yellow, 86\% for Uyole 98, 83\% for Uyole Njano, 81.5\% for Lyamungo 90, 79.5\% for Jesca and 72.3\% for Selian 97. The variety ranking after cooking did not differ much from the ranking of uncooked beans. Combining two seasons' assessment data resulted in Kigoma yellow ranking number one and Uyole 98 becoming number two. Third and fourth were Lyamungo 90 and Uyole njano, respectively.

\section{Economic analysis}

Available beans at the Kibondo market were only the local variety, Kigoma yellow, which were selling at Tshs $1,200 \mathrm{~kg}^{-1}$ at the time of harvesting. The exchange rate at the time was 1750 Tsh per USD. There were no differences in costs of production between the different bean varieties. Since the introduced varieties were not found in local markets, it was not known how these would have competed in terms of prices. Assuming the price to be TShs 1,200 per kilogram for each variety, and the maximum yield of the local variety without using fertilizer to be $600 \mathrm{~kg} \mathrm{ha}^{-1}$, an economic analysis for the average yields was performed and results are presented in Table 3. Uyole Njano produced the highest yield value per unit cost of production followed by Uyole 98. Jesca had the lowest yield value per unit cost of production (Table 3).

\section{DISCUSSION}

\section{Soils}

The correlations between soil $\mathrm{pH}$ and bean yields were not significant. However, it was observed for Kibondo district that lowest yield (689 Kg.ha- ${ }^{-1)}$ was obtained in the most acidic soil ( $\mathrm{pH} \mathrm{4.7;)} \mathrm{and} \mathrm{highest} \mathrm{yield} \mathrm{(689} \mathrm{Kg.ha-1)} \mathrm{in} \mathrm{the} \mathrm{least} \mathrm{acidic} \mathrm{soil.} \mathrm{There}$ were positive significant $(\mathrm{p}<0.05)$ correlations between soil exchangeable $\mathrm{K}$ and yield for the varieties Jesca, Lyamungo 90 and Selian 97, between soil available P and yield of Kigoma yellow and between total $\mathrm{N}$ and yield of Selian 97 (Table 1) Beans tend to have a high requirement for potassium [14]. The soils where the trial was conducted had potassium levels between 0.19 and $4.93 \mathrm{me} / 100 \mathrm{~g}$ soil, considered to be medium to high in light textured soils, and an additional $39.6 \mathrm{~kg} \mathrm{ha}^{-1} \mathrm{~K}_{2} \mathrm{O}$ was supplied with the basal fertilizer. The fertilizer also supplied the equivalent of $29.7 \mathrm{~kg} \mathrm{ha}^{-1} \mathrm{P}_{2} \mathrm{O}_{5}$, which is close to the recommendation for beans in Tanzania [9]. Poor soil conditions and intermittent or terminal drought are factors that contribute to the weak ability of Phaseolus vulgaris beans to nodulate and fix atmospheric nitrogen in symbiosis [4, 13, 15].

\section{Growth, pests and diseases}

Apart from environmental conditions of rainfall and temperature, bean yields are also influenced by growth vigour, canopy cover, pests and diseases infestations. Rainfall

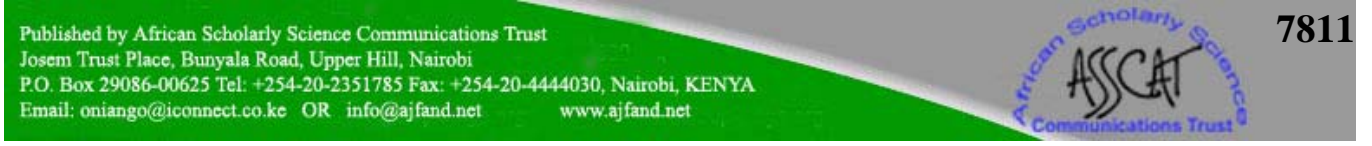




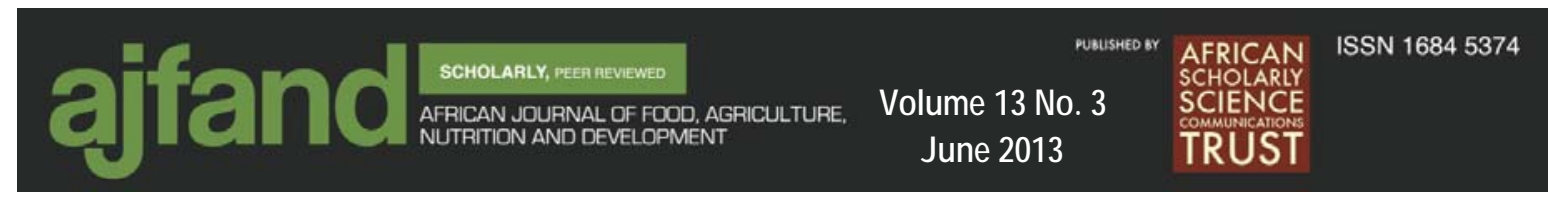

and temperature also influence the prevalence of some bean diseases [16]. Different bean varieties respond differently to such conditions. The varieties Jesca and Kigoma yellow, which were poorest in vigour and canopy cover in the first season, mature earlier than the other varieties. As such their critical growth periods coincided with a drought period that seriously affected growth vigour and canopy cover. These differences could not be seen in subsequent seasons because of a more even distribution of rainfall.

In the first season no control measures were applied, purposely to see how the different varieties could perform without pest and disease control measures, that is why diseases and pests were recorded only in that season. Diseases affect varieties differently because new breeds are usually bred to be resistant. Thus the local variety was affected by more diseases than any of the introduced varieties, but was not affected by anthracnose. It is not yet clear why the variety Lyamungo 90, bred for resistance to anthracnose, was affected most by the disease. The first notion is that there is a great possibility of resistance break down in that variety.

The first season which had frequent drought periods had also a high level of leaf damage by chewing insects, an indication that the alternate drought and rainy pattern was more favorable to such pests. Persistent rainfall has a washing effect of pests, including aphids, from leaves; this was also observed by some farmers. In subsequent seasons no serious diseases or pests were observed because control measures were applied. The weather was also very favorable in the last two seasons and plants grew very well.

\section{Yield performance}

In the first year, the crop was very seriously affected by drought in Kasulu district and this must have contributed to low yield averages. The differences in yield between the two districts can be attributed mainly to environmental differences in rainfall and temperature between the two districts, especially at the trial sites.

However, these yields were comparable to, or higher than, those of other producing countries in 1975 as follows in $\mathrm{kg} \mathrm{ha}^{-1}$ : India with yields of only 313; China, 937, Brazil, 563, Mexico, 801, Mauritius 250 - 1,500, Egypt 500, Kenya and Malawi 300 - 1,000, Great Britain 1,200 and the US 1332 [17].

Yields of the improved varieties in many cases surpass reported increases in recent years. In 2001-2007 adoption of new high yielding bean varieties in Tanzania has led to a steady increase in average yields from 480 to $770 \mathrm{~kg} \mathrm{ha}^{-1}$ [1].

The potential yields for these varieties can be perceived by the maximum yields obtained. The maximum yields were obtained in either year two or year three as shown in Table 2, which also compares these yields with the potential yields given by the breeders where available. In Kasulu district, all but Kigoma yellow varieties achieved their maximum yields in the third season, while in Kibondo maximum yields

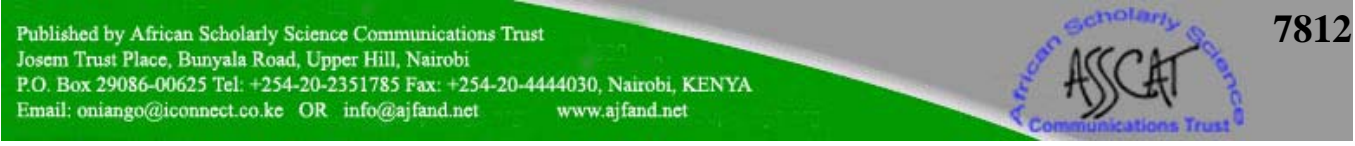




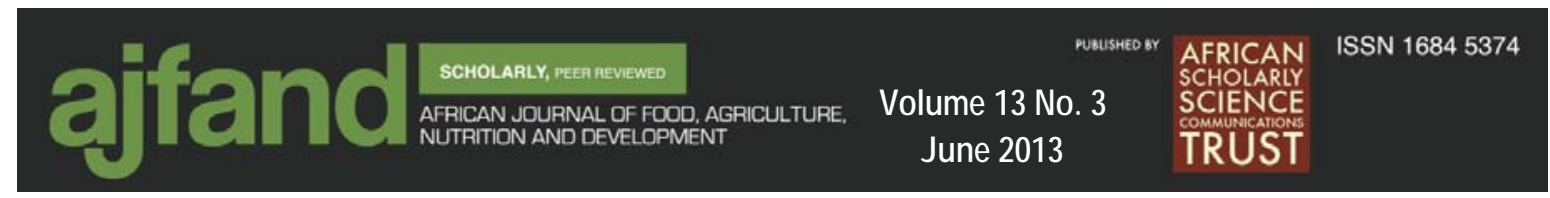

for all but Jesca varieties were achieved in the second season, implying that bean yields are influenced by seasonal weather variation.

Drought was more frequently observed in Kasulu than in Kibondo district, particularly in the first two seasons.

\section{Farmers' assessment}

One would consider that size, shape and colour of the beans are the main contributors to the marketability of beans. Taste, although not visually discernible, is also a contributing factor to marketability for known varieties. People of Kigoma are fond of the yellow beans as they are considered to go well with palm oil when cooking, and this cooking oil is widely available in the Region. It is probably due to this reason that the yellow and orange colored Uyole varieties received high acceptability (preference) scores. Farmers' scores on marketability were that Kigoma yellow (3.75 \pm 1.37$)$ was the most marketable variety, followed by Uyole 98 (3.23 \pm 1.48$)$. These two are fairly similar in appearance.

\section{Economic analysis}

This analysis considered only the local bean market in Kigoma, Tanzania, where the yellow colour of beans is an important criterion for marketability. The market in neighboring countries, particularly in Burundi, has a higher demand for the nonyellow varieties like JESCA, Lyamungo 90 and Selian 97 than the yellow varieties like Kigoma yellow. But price fluctuations there do not encourage increased production in Kigoma. Bean prices per kilogram in Bujumbura have dropped from USD 0.85 in May 2010 to USD 0.70 in July 2011 [18]. At the rate of TShs 1,750 per USD, the July price in Bujumbura is more or less the same as in Kigoma.

Since the ratio between the value of yield increase and the increase in cost to obtain that yield increase was highest for Uyole Njano followed very closely by Uyole 98, production of these two varieties using the inputs under consideration should be more profitable. The ratio was negative for Jesca, implying that this variety cannot be considered for the local market (Table 3).

\section{CONCLUSION AND RECOMMENDATIONS}

Considering the mean data, the varieties Uyole Njano and Uyole 98 produced highest yields at $1199 \mathrm{~kg} \mathrm{ha}^{-1}$ and $1175 \mathrm{~kg} \mathrm{ha}^{-1}$ respectively. Mean yields for the other varieties were less than $1,000 \mathrm{~kg} \mathrm{ha}^{-1}$. Despite yield differences between the two districts, the variety performance trend was similar for the two districts. This means that bean production in the two districts can be improved by adopting the high yielding varieties from research institutions.

Performance of the farmers' variety was improved by using fertilizer, pesticides and disease control chemicals, which could be the option in case of non availability of improved seeds. The benefit of applying these inputs to Kigoma yellow was not

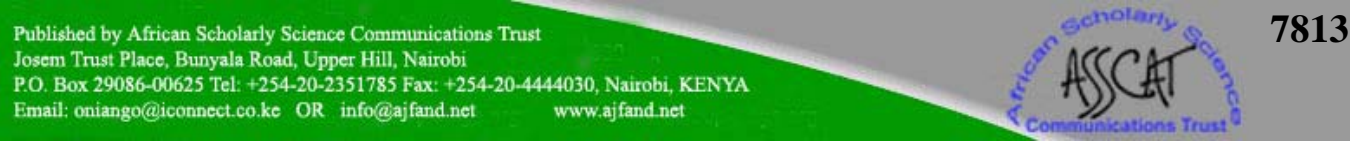




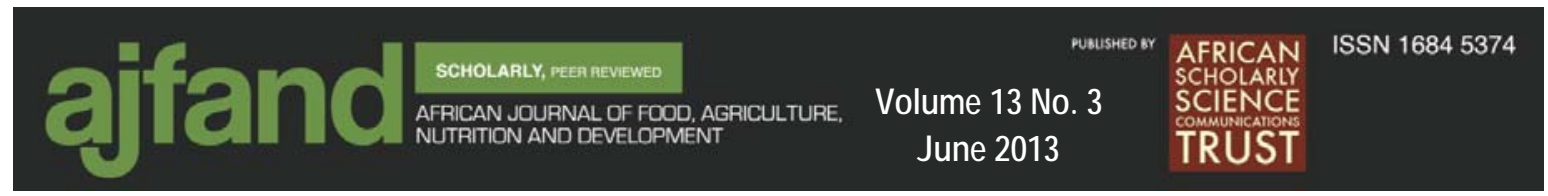

attractive. Farmers' assessment showed that Kigoma yellow was the most preferred variety and both Uyole Njano and Uyole 98 fall high on the farmers' ranks.

In view of the yields, farmers' preferences and economic superiority, Uyole Njano and Uyole 98 can be promoted as alternative varieties to Kigoma yellow, which despite being highly liked by farmers, produced low yields even with fertilizer application.

The economic analysis shows that recovery of fertilizer costs applied to the Kigoma yellow variety cannot be guaranteed.

It is recommended to promote cultivation of the varieties Uyole 98 and Uyole Njano in Kasulu and Kibondo districts in order to increase bean production in the two districts. A training programme on production of quality declared seeds (QDS) techniques needs to be initiated so that farmer groups can be able to engage in seed production. Bean seeds are not channeled through the normal agro-shops, like maize and some vegetable seeds, but depend instead on institutional supply. Bean production by farmer groups will be the easiest way to make bean seeds available to the majority of farmers. Subsidizing inputs for this crop as well by the national agriculture subsidy systems is recommended because beans are important in the economy of Kigoma Region.

\section{ACKNOWLEDGEMENTS}

This work was funded by the Principal Secretary Ministry of Agriculture, Food Security and Cooperatives, United Republic of Tanzania. Support and cooperation was extended to us by the district and ward authorities, as well as the participating farmers. The management and staff of ARI -Tumbi Tabora supported us in one way or another to accomplish the study. We are very grateful to all. Special thanks are due to our technicians Mr. E. Shinanda and Mrs.P. Rweyemamu, who had been very close to the farmers throughout. 


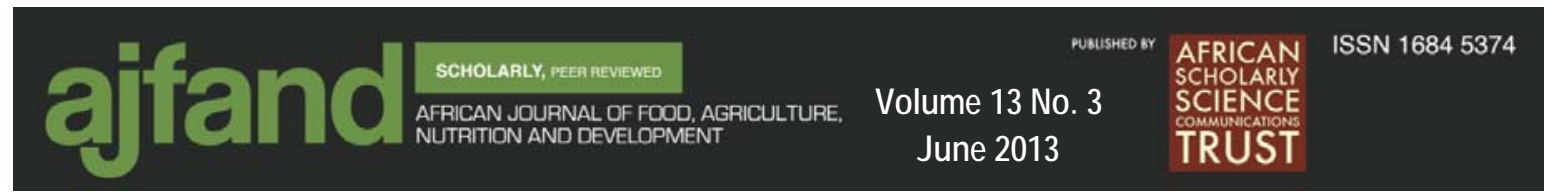

Table 1: Correlation coefficients between yields and some properties of the soils at the trial sites

\begin{tabular}{|l|c|c|c|c|}
\hline \multirow{2}{*}{ Soil properties } & \multicolumn{3}{|c|}{ Varieties and coefficients of correlation } \\
\cline { 2 - 5 } & Jesca & Lyamungo 90 & Kigoma yellow & Selian 97 \\
\hline pH H2O & 0.37 & 0.35 & 0.21 & 0.28 \\
\hline \% Organic carbon (OC) & 0.10 & 0.04 & 0.17 & 0.01 \\
\hline \% Nitrogen (N) & 0.15 & 0.40 & 0.30 & $0.49^{*}$ \\
\hline Carbon:N ratio & 0.22 & 0.42 & 0.13 & $0.49^{*}$ \\
\hline Available Phosphorus mg.kg-1 & 0.17 & 0.38 & $0.55^{*}$ & 0.37 \\
\hline CEC Me.100g-1 & 0.11 & 0.10 & 0.06 & 0.09 \\
\hline Exchangeable Ca Me.100g-1 & 0.11 & 0.33 & 0.18 & 0.40 \\
\hline Exchangeable Mg Me.100g-1 & 0.02 & 0.15 & 0.05 & 0.25 \\
\hline Exchangeable K Me.100g ${ }^{-1}$ & $0.63^{*}$ & $0.66^{*}$ & 0.42 & $0.59^{*}$ \\
\hline Exchangeable Na Me.100g-1 & $0.46^{*}$ & 0.10 & 0.04 & 0.18 \\
\hline Total Exch. Bases Me.100g-1 & 0.19 & 0.39 & 0.18 & $0.46^{*}$ \\
\hline \% Base saturation & $0.50^{*}$ & 0.32 & 0.29 & 0.40 \\
\hline Electrical conductivity mS.cm & & & & \\
\hline & 0.38 & 0.43 & & \\
\hline
\end{tabular}

$* \mathrm{P}=<0.05$ 


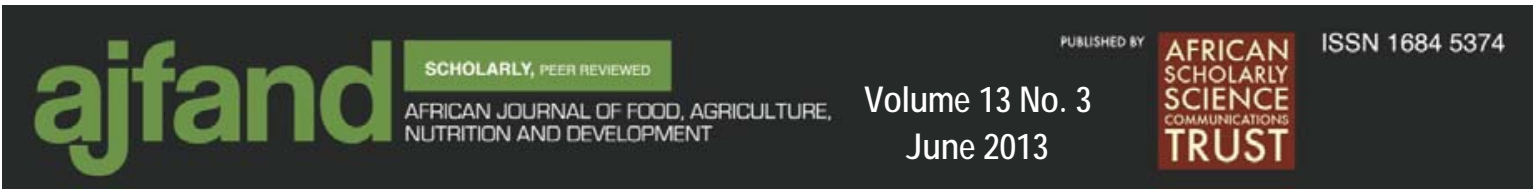

Table 2: Maximum yields and year obtained compared to given potential yields in $\mathrm{kg} \mathrm{ha}^{-1}$

\begin{tabular}{|c|c|c|c|c|c|}
\hline \multirow[b]{3}{*}{ Variety } & \multicolumn{4}{|c|}{ District and (Year) } & \multirow{3}{*}{$\begin{array}{c}\text { Potential Yield } \\
\text { Kg.ha' }^{-1}\end{array}$} \\
\hline & \multicolumn{2}{|c|}{ Kasulu } & \multicolumn{2}{|c|}{ Kibondo } & \\
\hline & $\begin{array}{c}\text { Maximum } \\
\text { yields } \\
\text { Kg.ha }^{-1}\end{array}$ & $\begin{array}{c}\text { Year } \\
\text { Obtained }\end{array}$ & $\begin{array}{c}\text { Maximum } \\
\text { yields } \\
\text { Kg.ha }^{-1}\end{array}$ & $\begin{array}{c}\text { Year } \\
\text { Obtained }\end{array}$ & \\
\hline Uyole 98 & 2704 & Third & 3275 & Second & $1500-2000$ \\
\hline JESCA & 1473 & Third & 1700 & Third & $2000-3400$ \\
\hline Uyole Njano & 2225 & Third & 3075 & Second & $3000-3500$ \\
\hline Selian 97 & 2452 & Third & 2250 & Second & $2000-3400$ \\
\hline Lyamungo 90 & 2360 & Third & 2063 & Second & $2000-3500$ \\
\hline Kigoma Yellow & 1700 & Second & 2275 & Second & - \\
\hline
\end{tabular}


Table 3: Economic analysis considering three year average yields

\begin{tabular}{|c|c|c|c|c|c|c|c|}
\hline & \multicolumn{7}{|c|}{ VARIETIES } \\
\hline & K.Yellow * & K. yellow & Uyole 98 & Uyole nj. & Lya.90 & Sel.97 & Jesca \\
\hline \multirow{2}{*}{ Yield Kg.ha-1 } & \multirow{2}{*}{600} & $674 \pm$ & $1,175 \pm$ & $1,199 \pm$ & $822 \pm$ & $841 \pm$ & $584 \pm$ \\
\hline & & 265.5 & 563.8 & 540.4 & 294.5 & 331.2 & 244.2 \\
\hline Price Shs.kg-1 & 1,200 & 1,200 & 1,200 & 1,200 & 1,200 & 1,200 & 1,200 \\
\hline Value Shs.ha-1 & 720,000 & 808,800 & $1,410,000$ & $1,438,800$ & 986,400 & $1,009,200$ & 700,800 \\
\hline V. I shs.ha-1 & 0 & 128,800 & 690,000 & 718,800 & 266,400 & 289,200 & $-19,200$ \\
\hline Seeds Kg.ha-1 & 25 & 25 & 25 & 25 & 25 & 25 & 25 \\
\hline Seed price Shs.kg-1 & 1,200 & 1,200 & 2,000 & 2,000 & 2,000 & 2,000 & 2,000 \\
\hline Seeds shs.ha-1 & 30,000 & 30,000 & 50,000 & 50,000 & 50,000 & 50,000 & 50,000 \\
\hline Fert. NPK Kg.ha-1 & 0 & 82.5 & 82.5 & 82.5 & 82.5 & 82.5 & 82.5 \\
\hline NPK shs. $\mathrm{Kg}^{-1}$ & 1,400 & 1,400 & 1,400 & 1,400 & 1,400 & 1,400 & 1,400 \\
\hline Fert. Shs.ha-1 & 0 & 115,500 & 115,500 & 115,500 & 115,500 & 115,500 & 115,500 \\
\hline Labour Md/ha-1 & 0 & 10 & 10 & 10 & 10 & 10 & 10 \\
\hline Labour shs.md ${ }^{-1}$ & 3,000 & 3,000 & 3,000 & 3,000 & 3,000 & 3,000 & 3,000 \\
\hline Labour shs.ha ${ }^{-1}$ & 0 & 30,000 & 30,000 & 30,000 & 30,000 & 30,000 & 30,000 \\
\hline TVC shs.ha ${ }^{-1}$ & 30,000 & 175,500 & 195,500 & 195,500 & 195,500 & 195,500 & 195,500 \\
\hline CI shs.ha ${ }^{-1}$ & 0 & 145,500 & 165,500 & 165,500 & 165,500 & 165,500 & 165,500 \\
\hline Net Value shs.ha-1 & 690,000 & 622,300 & $1,214,500$ & $1,243,300$ & 790,900 & 813,700 & 505,300 \\
\hline Net value/TVC & 23 & 3.5 & 6.2 & 6.4 & 4.0 & 4.2 & 2.6 \\
\hline Value (inc)/CI. & 0.0 & 0.9 & 4.2 & 4.3 & 1.6 & 1.75 & -0.1 \\
\hline
\end{tabular}

$*=$ Farmers practice $\quad$ TVC $=$ Total variable Costs $\mathrm{CI}=$ Cost of increase $\mathrm{nj}=$ njano,

Sel= Selian, Ly= Lyamungu K= Kigoma $\quad$ V. I =Value of Increase 


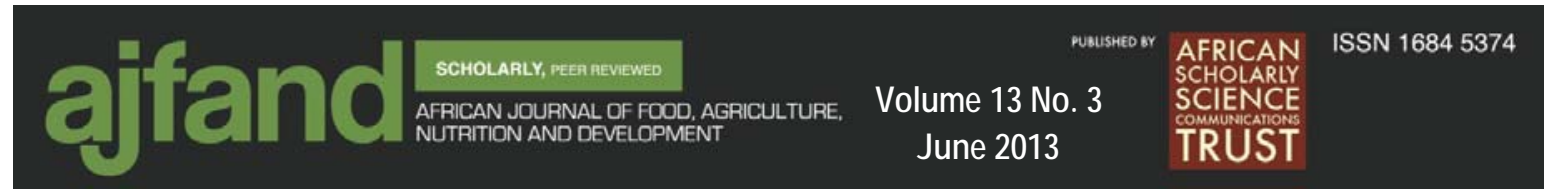

\section{REFERENCES}

1. Katungi E, Farrow A, Chianu J, Sperling $\mathbf{L}$ and S Beebe Common bean in Eastern and Southern Africa: A situation and outlook analysis. International Centre for Tropical Agriculture, 2009.

2. Onwueme IC and TD Sinha Field Crop Production in Tropical Africa. The Technical Centre for Agricultural and Rural Co-operation (CTA), Ede, the Netherlands, 1991.

3. Wortman CS Phaseolus vulgaris $L$ (common bean) [Internet] Record from Protabase. In Brink M and G Belay (Editors). PROTA (Plant Resources of Tropical Africa/Ressources vegétalés de l'Afrique tropicalé). Wageningen, Netherlands <http://database.prota.org/search.htm> Accessed 25/05/2012.

4. Graham PH and P Ranalli Common bean (Phaseolus vulgaris L.). Field Crops Research 1997; 53: 131-146.

5. United Republic of Tanzania (URT). Kigoma Region social Economic profile, 1998.

6. Allen DJ Bean Production Systems in Africa study guide CIAT, 1986: (series: 04 EB.01) 16p.

7. BACAS (Bureau for Agriculture consultancy and Advisory service) Final report on Baseline survey on the Agricultural Research System under the Department of Research and Development. Volume 1. Western Zone Synthesis of main Findings and Recommendations, Sokoine University of Agriculture, Morogoro, Tanzania, 2000.

8. Hillocks RJ, Madata CS, Chirwa R, Minja EM and S Msolla Phaseolus bean improvement in Tanzania 1959-2005; 2006. Springer. http://ciatlibrary.ciat.cgiar.org/articulos/ciat/paperb..Accessed on 27 October 2011.

9. Kanyeka E, Kamala $\mathbf{R}$ and $\mathbf{R}$ Kasuga Improved Agricultural Technologies Recommended in Tanzania. The Department of Research and Training, Ministry of Agriculture Food Security and Cooperatives, Dar Es Salaam, Tanzania, 2007.

10. Beaver JS, Rosas JC, Myers J, Acosta J, Kelly JD, Nchimbi-Msolla S, Misangu R, Bokosi J, Temple S, Arnaud-Santana E and DP Coyne Contribution of the Bean/Cowpea CRSP to cultivar and germplasm development in common bean. Field Crops Research 2003: 87-102.

11. Wim Buysse, Roger Stern, Ric Coe and Crispin Matere GenStat Discovery Edition for every day use, 2007: 117pp. ICRAF; Nairobi, Kenya. 


ajfand

12. SPSS for Windows (Chicago IL., USA) Version 11.5.

13. Graham PH, Rosas JC, Estevez de Jensen C, Peralta E, Tlusty B, AcostaGallegos J and PA Atraes Pereira Addressing edaphic constraints to bean production: The bean/cowpea CRSP project in perspective. Field Crops Research 2003: 179-192.

14. Mackenzie RH, Seward K, Gudiel R and BL Westco Dry Bean Nutrient Requirements in Southern Alberta. Plant Industry Division, AAFRD, Lethbridge 1999; (403): 381-5842.

15. Graham PH Some problems in nodulation and symbiotic nitrogen fixation in Phaseolus vulgaris. Field Crops Research 1981; 4: 93-112.

16. Walter JK Important Diseases and Pests of bean (Phaseolus vulgaris) Lima bean (Phaseolus lunatus) and Pigeon pea (Cajanus cajan) in Africa. Afr. J. Pl. Prot. 1976; 1: 97-102.

17. Duke J A Handbook of Energy Crops. Centre for New Crops \& Plants products. Purdue University electronic publication, 1983.

18. FAO GIEWS Food Production Data and analysis Tool. http://www.fao.org/giews/pricetool2/. Accessed on 27 October 2011. 